\title{
Comparative Analysis of Antioxidant Properties and Fruit Quality Attributes of Organically and Conventionally Grown Melons (Cucumis melo L.)
}

\author{
Karen Salandanan \\ Department of Horticulture and Landscape Architecture, Colorado State \\ University, Fort Collins, CO 80523-1173
}

Marisa Bunning

Department of Food Science and Human Nutrition, Colorado State University, Fort Collins, CO 80523-1173

Frank Stonaker

Department of Horticulture and Landscape Architecture, Colorado State University, Fort Collins, CO 80523-1173

Oktay Külen

Genetic Engineering \& Biotechnology Institute P.K.:21 41470, Gebzel Kocael, Tubitak, MAM, Turkey

\section{Patricia Kendall}

Department of Food Science and Human Nutrition, Colorado State University, Fort Collins, CO 80523-1173

\section{Cecil Stushnoff ${ }^{1}$}

Department of Horticulture and Landscape Architecture, Colorado State University, 113B Shepardson, Fort Collins, CO 80523-1173

Additional index words. total phenolics, ascorbic acid, soluble solids, dry matter, DPPH, ABTS

\begin{abstract}
Antioxidant properties and quality attributes were evaluated for 10 melon (Cucumis melo L.) cultivars grown under conventional and certified organic conditions in a 2-year field study. Differences among cultivars, produced either by conventional or organic methods, contributed the largest sources of variation in antioxidant properties. A 2.1- to 2.2-fold difference was seen between groups of cultivars with the highest and lowest levels of ascorbic acid when produced by organic and conventional methods, respectively. Choice of cultivar using conventional and organic production, respectively, enabled a 1.7- and 1.6-fold gain in total phenolics, a 2.6- and 4.2-fold gain in radical scavenging capacity determined by 2,2 ' -azinobis (3-ethylbenzthiazoline-6-sulfonic acid), and a 1.8- and 2.4-fold gain determined by the 2,2-diphenyl-1-picrylhydrazyl assay. Based on an antioxidant index, cultivars with the highest antioxidant properties were Savor, Sweetie \#6, Early Queen, Edonis, and Rayan. Organic melons had significantly higher ascorbic acid over both years, whereas total phenolics content was higher only in the first year. Percent dry matter and soluble solids content also varied widely among cultivars but were unaffected by production system. Choice of cultivar provides a viable option for growers interested in producing melons with high antioxidant properties. Cultivars with high antioxidant levels may provide a competitive marketing and supply niche for producers, but the full extent of diversity for antioxidant attributes requires further evaluation of cultivars and germplasm.
\end{abstract}

Consumer demand for fruit and vegetables, including Cucumis melo L. (muskmelon), has increased over the past two decades (Lucier and Jerardo, 2007; Pollack, 2001), some of which may be the result of growing awareness of contributions to good nutrition and human health. Along with evidence of nutritional benefits, demand for organic produce continues to grow as consumers seek high-quality fresh products from local markets. Organic produce is perceived to be safe, environmentally friendly, and of high quality (Brandt and Molgaard, 2001; Yiridoe et al., 2005). Some reports have shown that organic produce is higher in ascorbic acid, phenolic content, total sugars, and micronutrients (Caris-Veyrat et al., 2004; Ren et al., 2001; Weibel et al., 2000). A recent marketing survey suggests that healthaware consumers are willing to pay a premium for produce that has been documented by unbiased sources to contain higher nutri- ent levels and enhanced antioxidant properties (Thilmany et al., 2007).

Although most antioxidants are not considered as nutrients per se, with recommended daily intake amounts, recent research reports suggest potentially valuable roles in human nutrition, especially in intervention and prevention of cancer, heart, and other chronic diseases (Bazzano et al., 2003; Cheng et al., 2007; Czernichow et al., 2004; van't Veer et al., 2000). Antioxidants are known to suppress the formation of reactive oxygen species and to restore integrity of damaged DNA (Lister, 2003). Although fruits and vegetables are recognized as the best dietary sources of antioxidants, the amount and type of each are influenced by a number of factors, including genotype, ontogeny, environment, and postharvest handling (Butelli et al., 2008; Lata, 2007; Schreiner and Huyskens-Keil, 2006; Zhao et al., 2007). Production systems (organic versus conventional) have been shown to affect antioxidants in some but not all cases (Asami et al., 2003; Lombardi-Boccia et al., 2004). Because comprehensive high-throughput analytical screening of genotypes for nutrient properties is in its infancy, choice of cultivars has only been superficially examined as a means of enhancing nutritional attributes. Health-conscious consumers who are aware of positive attributes associated with safe and nutritious fresh produce are more likely to seek and demand such cultivars once they are made aware of differences. Studies that systematically compare antioxidant properties of organic and conventional melons, especially the differences among cultivars, are limited. In this study, we examined ascorbic acid (AA), total phenolics (TP), radical scavenging capacity $2,2^{\prime}$-azinobis (3-ethylbenzthiazoline-6-sulfonic acid) (ABTS), and 2,2-diphenyl-1-picrylhydrazyl (DPPH) as Trolox-equivalent antioxidant properties (TEAC), dry matter, and soluble solids concentration (SSC) in the same 10 cultivars grown in the same location, on the same soil texture and type, using organic and conventional practices for 2 consecutive years. This study had four primary objectives: 1) to evaluate antioxidant properties, including AA, TP, ABTS/TEAC, DPPH/ TEAC, and quality attributes among $10 \mathrm{C}$. melo cultivars; 2) to examine 10 cultivars that may benefit small- and medium-scale growers seeking niche markets for melons with high antioxidant properties; 3 ) to examine if organic production results in higher or lower antioxidant levels using research parameters that minimize experimental variables; and 4) to examine, to the extent possible, variation among antioxidant and quality attributes impacted by environmental conditions in 2 consecutive years.

\section{Materials and Methods}

Temperature and solar radiation. Data on temperature and solar radiation for two cropping seasons (2005-2006) were obtained from a Northern Colorado Water Conservancy 
Table 1. Classification and description of melon cultivars.

\begin{tabular}{|c|c|c|}
\hline Melon type & Cultivar & Description \\
\hline \multirow[t]{2}{*}{ Galia } & Arava & Fragrant with soft green flesh; rind blush of gold when ripe, finely netted, nearly sutureless \\
\hline & Haogen & $\begin{array}{l}\text { Green-fleshed (similar to a muskmelon); rind is smooth, has gold mottled lobes and } \\
\text { green sutures when ripe }\end{array}$ \\
\hline \multirow[t]{2}{*}{ Muskmelon (cantaloupe) } & Burpee Hybrid & Flesh is thick and deep orange in color; rind is gold with heavy netting when ripe and has deep sutures \\
\hline & Early Queen & Muskmelon hybrid with orange flesh; rind is full gold with medium lobes when ripe \\
\hline \multirow[t]{3}{*}{ Charentais } & Edonis & $\begin{array}{l}\text { French melon with orange flesh and honey orange in color; rind has green sutures and } \\
\text { golden lobes when ripe; fail to slip easily }\end{array}$ \\
\hline & Savor & $\begin{array}{l}\text { Classic Charentais type, sweet and aromatic; rind has green sutures and golden lobes when ripe; } \\
\text { fail to slip easily }\end{array}$ \\
\hline & Swan Lake & $\begin{array}{l}\text { White flesh with some orange swirls; rind has golden lobes and whit sutures when ripe; } \\
\text { fail to slip easily }\end{array}$ \\
\hline Honeydew & Honey Orange & Pale orange flesh honeydew; rind is light green with hint of gold when ripe \\
\hline Ananas & Rayan & $\begin{array}{l}\text { Elongated shape with sweet, greenish white flesh; rind is green turning a hint of dark gold when ripe, } \\
\text { nearly sutureless }\end{array}$ \\
\hline Butterscotch & Sweetie \#6 & $\begin{array}{l}\text { Sweet and fragrant flavor; rind remains very green with a tinge of blue on ripening, and red } \\
\text { exudates begin appearing at connection point of fruit and stem }\end{array}$ \\
\hline
\end{tabular}

District weather station located within $100 \mathrm{~m}$ of the research plots. To examine possible effects of temperature, daily growing degreeday heat accumulation units were computed by subtracting the base temperature $\left(10{ }^{\circ} \mathrm{C}\right)$ for warm season crops from the average temperature as daily GDD $=\left[\left(\mathrm{T}_{\max }+\mathrm{T}_{\min }\right) /\right.$ 2 ] - base temperature in which $T_{\max }$ and $T_{\min }$ are maximum and minimum daily air temperatures. Each daily GDD was summed over the growing season. Solar radiation data were recorded with an "Epply" pyranometer and expressed as Langleys (1-calories $/ \mathrm{cm}^{2}$ ).

Melon production and handling. The study was carried out with field plot trials in 2005 and 2006 at the Horticulture Field Research Center, Colorado State University, Fort Collins, CO. The research plots were certified organic by the Colorado Department of Agriculture in accordance with the National Organic Program standards. Conventional production plots were located within $50 \mathrm{~m}$ on identical soil texture (Nunn clay, $\mathrm{pH}$ 7.8) and were managed with inorganic fertilizers and insecticides.

This study is part of a larger project from USDA/CSREES/NRI entitled "Differentiating Small Farm Produce Offerings through Nutritionally Superior Cultivars, Marketing, and Extension Programs," in which six crops, including melons, were planted on conventional and certified organic fields. The experimental units were laid out in a split plot with the whole plots arranged as a completely randomized design. Production sys-

\footnotetext{
Received for publication 15 May 2009. Accepted for publication 31 July 2009 .

This project was supported by the National Institute of Food and Agriculture, USDA Cooperative State Research, Education and Extension Service, NRI grant number 2005-55618-15634, and Colorado State Agricultural Experiment Station Project number 0691.

We gratefully acknowledge The Fulbright-Philippine Agriculture Scholarship Program for graduate studies support of Karen Salandanan. We thank James zumBrunnen for statistical advice and Heather Troxell and Jeannette Stushnoff for technical assistance.

${ }^{1}$ To whom reprint requests should be addressed; e-mail Cecil.Stushnoff@ColoState.EDU.
}

tems were assigned to whole plots and cultivars were designated as subplots. Three blocks in each production system served as replications. Each $163-\mathrm{m}^{2}$ organic or conventional production system was planted to 450 plants in the three replicate blocks that included 10 cultivars described in Table 1 . Cultivars were randomized within each replicate block. Transplants were grown from seed (Johnny's Selected Seeds, Inc., Winslow, ME) in the CSU Plant Environmental Research Center Greenhouses. Sunshine Organic Basic planting media (Sun Gro Horticulture, Bellevue, WA) was used to grow melon transplants in 7.6-cm round Jiffy peat pots for $21 \mathrm{~d}$ before transplanting in the field. The transplants were grown on a bottomheated greenhouse floor maintained at $18{ }^{\circ} \mathrm{C}$. Rootshield ${ }^{\circledR}$ (Trichoderma harzianum, Rifai, Strain T-22 \#9462; Bioworks, Victor, $\mathrm{NY}$ ), approved for use in organic crops, was drenched into the soil immediately after sowing for all plants. Melons were transplanted into black plastic mulched beds at $61-\mathrm{cm}$ spacing between plants and $183 \mathrm{~cm}$ between beds. The field plots measured $44.5 \mathrm{~m}$ long and $11.0 \mathrm{~m}$ wide.

Fertilization. Preplant soil samples were used to manage application rates of organic and conventional fertilization. Postplanting soil tests to monitor fertility levels were taken at $7.6 \mathrm{~cm}$ off the irrigation drip tape and to a depth of $25.4 \mathrm{~cm}$. Evergreen poultry compost (A-1 Organics, Eaton, CO) was applied preplanting at $22,679 \mathrm{~kg} \cdot \mathrm{ha}^{-1}$ to the organic plots. The compost was applied with a Mill Creek spreader (Mill Creek Spreader, Leola, PA) and rototilled into the soil immediately after application. To match nutrient levels of the organic block, $389 \mathrm{~kg} \cdot \mathrm{ha}^{-1}$ of urea $(45 \mathrm{~N}-$ 0P-0K) and $882 \mathrm{~kg} \cdot \mathrm{ha}^{-1}$ of triple superphosphate $(0 \mathrm{~N}-20.1 \mathrm{P}-0 \mathrm{~K})$ were applied to the conventional block using a broadcast spreader before incorporation.

Pest management. Cucumber beetle ( $\mathrm{Aca}$ lymma vittatum, Fabricius) pressure on the transplants was more intense for both organic and conventional plots in 2005 than in 2006. To minimize the infestation, a synthetic insecticide, Permethrin (Zeneca Ag Products, Wilmington, DE), was applied in conventional plots at a rate of $0.3 \mathrm{~L} \cdot \mathrm{ha}^{-1}$, whereas naturally derived pyrethrum Pyganic EC 5.0 (MGK Co., Minneapolis, MN) was used in the organic plots at a rate of $0.7 \mathrm{~L} \cdot \mathrm{ha}^{-1}$ both in 2005 and in 2006. These pesticides were applied using a Stihl SG-20 motorized backpack sprayer (Stihl, Virginia Beach, VA).

Irrigation management. Research plots were irrigated with a city of Fort Collins domestic water source, $\mathrm{pH}=7.9$, and a low calcium carbonate hardness rating of 48.2 $\mathrm{mg} \cdot \mathrm{L}^{-1}$. Water was applied using drip irrigation (Chapin Watermatics, Watertown, NY) and was scheduled using Watermark ${ }^{\circledR}$ granular matrix sensors (Irrometer, Co. Riverside, CA). Drip irrigation was applied at $0.063 \mathrm{~L} /$ $\mathrm{min} / \mathrm{m}$ per row, and application varied during the season from $0.5 \mathrm{~h} / 2 \mathrm{~d}$ to $2 \mathrm{~h} / \mathrm{d}$ to maintain water tension below $100 \mathrm{KPa}$. During the production period, crops were not permitted to suffer from water stress based on data from the Watermark soil monitors.

Harvesting and postharvest handling. Melons were harvested at full slip, which coincided with a rind color shift toward gold and senescence of the leaf closest to the fruit. Three uniform fruits of similar size and maturity were collected from each replication per cultivar and cooled after harvest to $1.1 \pm$ $0.5^{\circ} \mathrm{C}$ in a refrigerated cooler.

Sample preparation, extraction, and analysis. Melons were washed twice in tap water to remove surface contamination and cut transversely in the middle of each fruit. Forty grams of 4.0 to $6.0 \mathrm{~mm}$ thick radial melon slices without the skin were individually weighed for calculation of dry matter content, lyophilized in a Virtis freeze dryer (SP Industries, Warminster, PA), and stored desiccated in air-tight vials at $-20{ }^{\circ} \mathrm{C}$ before analysis. Samples were freeze-dried for 5 d until vacuum levels remained stable at 200 to 300 millitorr removing all freezable water. Freeze-dried melon samples were ground and passed through a 100-mesh screen to achieve a uniform particle size in preparation for extraction. Freeze-dried samples of $500 \mathrm{mg}$ were extracted in $10 \mathrm{~mL}$ of $80 \%$ acetone by vortexing and rotating for $1 \mathrm{~h}$ in the dark at $4{ }^{\circ} \mathrm{C}$ with a rotator (Barnstead/ Hemolyne, Dubuque, IA) before centrifugation at $6000 \mathrm{rpm}$ for $15 \mathrm{~min}$ at $4{ }^{\circ} \mathrm{C}$. Onemilliliter aliquots of clear supernatant were 
removed and concentrated to dryness in a Vacufuge ${ }^{\mathrm{TM}}$ [Eppendorf North America (Westbury, NY), VWR, CO] for $2 \mathrm{~h}$ at $45^{\circ} \mathrm{C}$. The concentrated extracts were reconstituted and analyzed for TP, ABTS, and DPPH. Because the Vacufuge ${ }^{T M}$ concentration step was shown in preliminary trials and in previous research (Esparaza-Rivera et al., 2006) to degrade essentially all vitamin $\mathrm{C}$, data for TP, ABTS, and DPPH antioxidant capacity are considered not to reflect a contribution from vitamin $\mathrm{C}$ as an antioxidant.

Total phenolics. TP was standardized against gallic acid (Sigma Chemicals Co., St. Louis, MO) and expressed as milligrams per $100 \mathrm{~g}$ of melon fresh weight (mg GAE/ 100 g FW) using a microplate-based FolinCiocalteu assay adapted from Spanos and Wrolstad (1990). Vacufuge concentrated samples were reconstituted with $1.0 \mathrm{~mL}$ $80 \%$ acetone (Fisher Chemicals, Fair Lawn, $\mathrm{NJ})$ and $100 \mu \mathrm{L}$ of this extract was diluted with $900 \mu \mathrm{L}$ of nanopure water. In triplicate, $35 \mu \mathrm{L}$ diluted samples were pipetted into 96well microplates. Using a multichannel pipette, $150 \mu \mathrm{L}$ of $0.2 \mathrm{M}$ Folin-Ciocalteu reagent (Sigma Chemicals Co.) and $115 \mu \mathrm{L}$ $7.5 \%$ (w/v) $\mathrm{Na}_{2} \mathrm{CO}_{3}$ (Sigma Chemicals Co.) were added to all wells. The plate was incubated at $45^{\circ} \mathrm{C}$, cooled to room temperature for $1 \mathrm{~h}$, and read at $765 \mathrm{~nm}$ using a Spectra Max Plus (Molecular Devices Corp., Sunnyvale, CA) spectrophotometer. Trolox-equivalent antioxidant capacity was assessed with two different assays.

ABTS $^{\cdot+}$ scavenging assay. $\mathrm{ABTS}^{\cdot+}\left[2,2^{\prime}-\right.$ azinobis (3-ethylbenzthiazoline-6-sulfonic acid)] (Calbiochem, EMD Biosciences, La Jolla, CA)/TEAC was measured using a microplate $\mathrm{ABTS}^{\cdot+}$ radical cation assay based on the method developed by Miller and Rice-Evans (1997). ABTS ${ }^{++}$solution was prepared by mixing $40 \mathrm{mg}$ ABTS in 15 $\mathrm{mL}$ distilled water and $2.0 \pm 0.5 \mathrm{~g}$ of $\mathrm{MnO}_{2}$ (Sigma Chemicals Co.). After 20 min with occasional stirring, the $\mathrm{MnO}_{2}$ was removed by vacuum filtration and a $0.2 \mu \mathrm{m}$ Acrodisk (VWR, Denver, CO) syringe filter. Absorbance of the ABTS ${ }^{\cdot+}$ solution was read at 734 $\mathrm{nm}$ in a Spectra Max Plus spectrophotometer and adjusted to 0.70 absorbance units (AU) by adding $5.0 \mathrm{~mm}$ phosphate buffer solution. Twenty-five microliters of reconstituted samples and $250 \mu \mathrm{L}$ of $\mathrm{ABTS}^{\circ+}$ solution was mixed well on a platform shaker and read at $734 \mathrm{~nm}$ after exactly $60 \mathrm{~s}$ at $25{ }^{\circ} \mathrm{C}$. The absorbance value was expressed as micromoles TEAC $/ \mathrm{mL}$ in assay and compared with a set of Trolox standards. This was converted to micromoles TEAC/100 g sample (FW) with linear regression taking into account all dilution and concentration factors.

$D P P H^{\bullet+}$ assay. Antioxidant activity was measured with a microplate-based 2,2diphenyl-1-picrylhydrazyl $\mathrm{DPPH}^{\cdot+}$ scavenging assay based on the method of $\mathrm{Lu}$ and Foo (2000) with some modifications. A $0.1 \mathrm{~mm}$ $\mathrm{DPPH}^{\cdot+}$ solution was prepared by mixing $7.89 \mathrm{mg}$ DPPH with $100 \%$ methanol and adjusting the absorbance value to $0.95 \mathrm{AU}$. Fifteen microliters of the reconstituted samples was
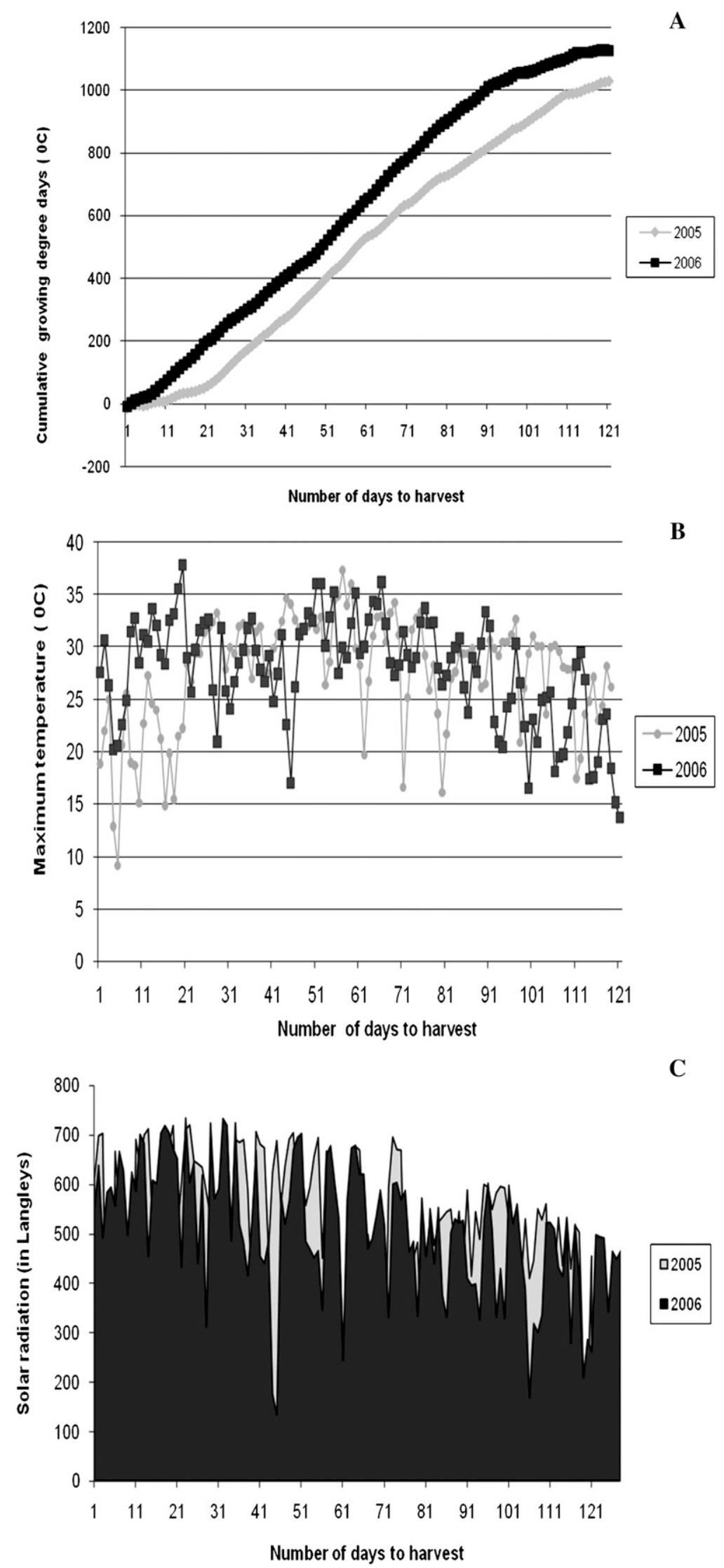

Fig. 1. (A) Heat accumulation [in growing degree-days (GDD) $]$ from planting to harvest GDD $=\left[\left(\mathrm{T}_{\max }+\right.\right.$ $\left.\left.\mathrm{T}_{\min }\right) / 2\right]-10{ }^{\circ} \mathrm{C}$, in which $\mathrm{T}_{\max }$ and $\mathrm{T}_{\min }$ are maximum and minimum daily air temperatures, respectively; $10{ }^{\circ} \mathrm{C}$ is the base temperature for warm season crops; (B) number of days with temperature greater than $30^{\circ} \mathrm{C}$ as an indicator of heat stress; (C) daily net solar radiation (Langleys) from planting to harvest. 
Table 2. Analysis of variance of the effects of year, cultivar, and production system and their interactions expressed as $P$ values for statistical significance. ${ }^{z}$

\begin{tabular}{|c|c|c|c|c|c|c|}
\hline Source & $\begin{array}{l}\text { Ascorbic } \\
\text { acid }\end{array}$ & $\begin{array}{c}\text { Total } \\
\text { phenolics }\end{array}$ & ABTS & DPPH & $\begin{array}{c}\text { Dry } \\
\text { matter }\end{array}$ & $\begin{array}{c}\text { Soluble } \\
\text { solids }\end{array}$ \\
\hline Year (Y) & $<0.01$ & $<0.01$ & $<0.001$ & $<0.01$ & $<0.01$ & $<0.01$ \\
\hline Cultivar (C) & $<0.0001$ & $<0.0001$ & $<0.0001$ & $<0.0001$ & $<0.0001$ & $<0.0001$ \\
\hline $\mathrm{Y} \times \mathrm{C}$ & $<0.0001$ & $<0.001$ & $<0.0001$ & $<0.01$ & $<0.0001$ & $<0.001$ \\
\hline Production system (PS) & $<0.05$ & $<0.01$ & NS & $<0.05$ & NS & NS \\
\hline $\mathrm{Y} \times \mathrm{PS}$ & NS & $<0.01$ & NS & NS & NS & NS \\
\hline $\mathrm{C} \times \mathrm{PS}$ & $<0.05$ & NS & $<0.0001$ & NS & NS & NS \\
\hline$\underline{\mathrm{Y} \times \mathrm{C} \times \mathrm{PS}}$ & $<0.01$ & $<0.001$ & $<0.0001$ & NS & NS & $<0.01$ \\
\hline
\end{tabular}

${ }^{{ }^{\mathrm{NS}}}=$ nonsignificant or significant at $P<0.05,0.01,0.001$.

mixed with $285 \mu \mathrm{L}$ of $\mathrm{DPPH}^{{ }^{+}}$solution and read at $515 \mathrm{~nm}$ in the spectrophotometer after exactly $3 \mathrm{~min}$ at $25{ }^{\circ} \mathrm{C}$. Results were expressed as microns DPPH/TEAC/100 g FW from linear regression of a Trolox standard curve taking into account all dilution and concentration factors.

Soluble solids content and percent dry matter. Soluble solids concentration of fresh melon tissue samples was measured using a temperature-compensated, handheld refractometer (Reichert, Depew, NY). The dry matter percentage was obtained gravimetrically from dried and fresh weights.

Ascorbic acid. Standard solutions were prepared by mixing $100 \mathrm{mg}$ dithiothreitol (Promega Corp., Madison, WI) and $10 \mathrm{mg}$ ascorbic acid (Sigma Chemicals Co.) and by diluting to five concentrations to prepare the standard curve. Lyophilized melon tissue was extracted in $5 \% \mathrm{w} / \mathrm{v}$ aqueous solution of metaphosphoric acid (VWR) containing 1\% w/v dithiothreitol (Sigma Chemicals Co.). The mixture was vortexed for $15 \mathrm{~s}$ and rotated for $15 \mathrm{~min}$ at $4{ }^{\circ} \mathrm{C}$. To separate the liquid from the solid phase, the refrigerated mixture was centrifuged for $5 \mathrm{~min}$ at $4000 \mathrm{rpm}$ at $4{ }^{\circ} \mathrm{C}$. This procedure was repeated twice. The supernatant from the first and second extractions was filtered through a $0.45-\mathrm{mm}$ nylon syringe filter (Acrodisk, VWR, Denver, CO) before injection onto an Inertsil 4C (Metachem; Thermo Fisher, St. Louis, MO) highperformance liquid chromatography (HPLC) column (Agilent Technologies, Santa Clara, CA) and run with a phosphoric acid/methanol gradient similar to Esparaza-Rivera et al. (2006). Samples prepared for ascorbic acid analysis by HPLC were not Vacufuge ${ }^{\mathrm{TM}}$ concentrated and were prepared shortly after freeze drying using actinic glassware at 0 to 4 ${ }^{\circ} \mathrm{C}$ until reacted with dithiothreitol before injection.

Statistical analysis. Analysis of variance was carried out using SAS Mixed Procedure (Version 9.1; SAS Inc., Cary, NC). Pearson correlation coefficients $(r)$ are from SAS. Differences between means use the TukeyKramer $(P \leq 0.05)$ method.

\section{Results}

Temperature, solar radiation, and precipitation. Melons accumulated more total heat units from field planting to harvest in 2006 than in 2005 (Fig. 1A), but in the last $30 \mathrm{~d}$ before harvest in 2005, melons were exposed to a larger number of greater than $30{ }^{\circ} \mathrm{C}$ days than in 2006 (Fig. 1B). Solar radiation received by crops from planting to harvest, including the $30 \mathrm{~d}$ before harvest, was almost the same for the 2 years (Fig. 1C).
Although natural precipitation in the 2006 growing season $(74 \mathrm{~mm})$ was only $35 \%$ of that received in $2005(222 \mathrm{~mm})$, irrigation was monitored and adjusted to avoid periods of drought stress in both years.

Influence of cultivar, production system, and year on antioxidant properties and quality attributes. Although data for all parameters measured varied significantly among cultivars, years, and cultivar-by-year interaction, production system had a significant effect only on ascorbic acid, TP, and DPPH antioxidant capacity (Table 2). The significant interaction between year and cultivar for all parameters indicates that environmental factors had a large effect on some cultivars but not on others. There was also a significant interaction between year and production system for $\mathrm{TP}$, indicating that TP was influenced by yearly environmental effects and production system. Cultivar and production system interactions implied that some cultivars had different levels of ascorbic acid and ABTS radical scavenging capacity when grown organically or conventionally, whereas others were unaffected by production system. Table 3 shows AA, ABTS, DPPH, and TP levels for organic and conventional production averaged over both years. Using Tukey-Kramer mean separation data presented in Table 3, mean values for cultivars in the highest and lowest mean separation ranges for each parameter measured are presented in Table 4 along with mean values for cultivars between the highest and lowest ranges classified as a midrange class. Cultivars within each of the high and low classes do not differ. Accordingly, average values of each class provide an indication of the gain or loss to be derived in selecting a cultivar and in choosing to produce by either conventional or by organic means for the antioxidant or quality parameters examined (Table 4).

Table 3. Antioxidant properties and total phenolics of melon cultivars grown under organic and conventional production $(2-\mathrm{yr}$ mean \pm SEM, $\mathrm{n}=6$ based on three replicate plots from 2005 and 2006).

\begin{tabular}{|c|c|c|c|c|c|}
\hline Production system & Cultivar & $\begin{array}{l}\text { Ascorbic acid } \\
(\mathrm{mg} / 100 \mathrm{~g} \mathrm{FW})\end{array}$ & $\begin{array}{c}\text { Total phenolics } \\
\text { (mg GAE/100 g FW) }\end{array}$ & $\begin{array}{c}\text { ABTS antioxidant capacity } \\
(\mu \mathrm{mol} \text { TEAC } / 100 \mathrm{~g} \mathrm{FW})\end{array}$ & $\begin{array}{c}\text { DPPH antioxidant capacity } \\
(\mu \mathrm{mol} \text { TEAC } / 100 \mathrm{~g} \mathrm{FW})\end{array}$ \\
\hline \multirow[t]{10}{*}{ Conventional } & Savor & $38.1 \pm 1.9 \mathrm{a}^{\mathrm{z}}$ & $71.7 \pm 6.1 \mathrm{a}$ & $220.5 \pm 39.0 \mathrm{a}$ & $301.5 \pm 22.2 \mathrm{a}$ \\
\hline & Sweetie \#6 & $34.2 \pm 1.4 \mathrm{a}$ & $64.0 \pm 5.9 \mathrm{ab}$ & $96.2 \pm 21.7 b c$ & $243.3 \pm 21.9 b$ \\
\hline & Burpee Hybrid & $26.5 \pm 2.8 b$ & $59.2 \pm 3.3 \mathrm{abc}$ & $112.8 \pm 27.6 \mathrm{bc}$ & $177.1 \pm 19.7 \mathrm{c}$ \\
\hline & Edonis & $23.0 \pm 4.0 \mathrm{bc}$ & $64.5 \pm 3.6 \mathrm{ab}$ & $169.5 \pm 21.5 \mathrm{ab}$ & $172.7 \pm 14.0 \mathrm{c}$ \\
\hline & Rayan & $22.2 \pm 1.3 \mathrm{bcd}$ & $53.9 \pm 4.5 \mathrm{bcd}$ & $100.1 \pm 17.0 \mathrm{bc}$ & $171.3 \pm 21.5 \mathrm{c}$ \\
\hline & Haogen & $21.2 \pm 2.3 \mathrm{bcd}$ & $40.5 \pm 4.7 \mathrm{~d}$ & $81.2 \pm 11.3 \mathrm{c}$ & $148.7 \pm 27.1 \mathrm{c}$ \\
\hline & Swan Lake & $19.8 \pm 0.9 \mathrm{cde}$ & $45.8 \pm 2.6 \mathrm{~cd}$ & $86.5 \pm 9.8 \mathrm{c}$ & $152.8 \pm 18.6 \mathrm{c}$ \\
\hline & Honey Orange & $19.2 \pm 1.8 \mathrm{cde}$ & $51.8 \pm 3.1 \mathrm{bcd}$ & $86.2 \pm 7.6 \mathrm{c}$ & $156.3 \pm 17.8 \mathrm{c}$ \\
\hline & Early Queen & $17.5 \pm 0.6 \mathrm{de}$ & $61.0 \pm 1.7 \mathrm{abc}$ & $190.7 \pm 28.5 \mathrm{a}$ & $185.5 \pm 6.4 \mathrm{c}$ \\
\hline & Arava & $16.2 \pm 1.0 \mathrm{e}$ & $41.7 \pm 1.7 \mathrm{~d}$ & $55.3 \pm 11.6 \mathrm{c}$ & $138.3 \pm 10.0 \mathrm{c}$ \\
\hline \multirow[t]{10}{*}{ Organic } & Savor & $38.0 \pm 3.4 \mathrm{a}$ & $65.7 \pm 2.8 \mathrm{abc}$ & $119.0 \pm 24.0 \mathrm{bcd}$ & $231.7 \pm 32.5 a$ \\
\hline & Sweetie \#6 & $37.8 \pm 1.9 \mathrm{a}$ & $68.7 \pm 4.3 \mathrm{a}$ & $220.7 \pm 75.1 \mathrm{a}$ & $194.8 \pm 16.2 \mathrm{ab}$ \\
\hline & Burpee Hybrid & $33.8 \pm 5.0 \mathrm{ab}$ & $63.5 \pm 8.4 \mathrm{abc}$ & $83.7 \pm 14.3 \mathrm{~cd}$ & $138.0 \pm 20.0 \mathrm{bcd}$ \\
\hline & Edonis & $27.3 \pm 3.0 \mathrm{bc}$ & $74.8 \pm 7.2 \mathrm{a}$ & $92.2 \pm 11.8 \mathrm{~cd}$ & $177.3 \pm 11.0 \mathrm{abc}$ \\
\hline & Rayan & $24.2 \pm 2.6 \mathrm{~cd}$ & $66.7 \pm 6.3 \mathrm{ab}$ & $163.7 \pm 49.9 \mathrm{ab}$ & $179.0 \pm 23.6 \mathrm{abc}$ \\
\hline & Haogen & $17.7 \pm 0.7 \mathrm{~d}$ & $52.3 \pm 9.8 \mathrm{bcd}$ & $52.7 \pm 13.0 \mathrm{~d}$ & $93.7 \pm 16.5 \mathrm{~d}$ \\
\hline & Swan Lake & $22.2 \pm 1.1 \mathrm{~cd}$ & $50.8 \pm 5.4 \mathrm{~cd}$ & $54.8 \pm 10.0 \mathrm{~d}$ & $127.8 \pm 22.6 \mathrm{~cd}$ \\
\hline & Honey Orange & $22.7 \pm 0.4 \mathrm{~cd}$ & $69.7 \pm 3.9 \mathrm{a}$ & $136.7 \pm 34.7 \mathrm{bc}$ & $131.5 \pm 5.8 \mathrm{~cd}$ \\
\hline & Early Queen & $25.2 \pm 1.2 \mathrm{~cd}$ & $69.5 \pm 7.3 \mathrm{a}$ & $116.2 \pm 18.2 \mathrm{bcd}$ & $178.2 \pm 10.4 \mathrm{abc}$ \\
\hline & Arava & $18.2 \pm 0.6 \mathrm{~d}$ & $44.7 \pm 4.3 \mathrm{~d}$ & $49.0 \pm 10.4 \mathrm{~d}$ & $96.3 \pm 8.5 \mathrm{~d}$ \\
\hline
\end{tabular}

zTreatment means within columns for each production system followed by the same letter are not significant at the $\alpha=0.05$ level according to the Tukey multiple comparison test. 
Table 4. Means derived from cultivars that were not significantly different within the highest and lowest classes. $^{\mathrm{z}}$

\begin{tabular}{|c|c|c|c|c|c|}
\hline \multicolumn{6}{|c|}{ Ascorbic acid (mg/100 g FW) } \\
\hline Class & Conventional & $\begin{array}{l}\text { Number of } \\
\text { cultivars }^{\mathrm{y}}\end{array}$ & Organic & $\begin{array}{l}\text { Number of } \\
\text { cultivars }^{\mathrm{y}}\end{array}$ & $\begin{array}{c}\text { Comparison } \\
\text { (organic/conventional) }\end{array}$ \\
\hline Highest & 36.2 & 2 & 37.9 & 2 & 1.0 \\
\hline Midrange & 21.3 & 7 & 28.0 & 6 & 1.3 \\
\hline Lowest & 16.2 & 1 & 17.9 & 2 & 1.1 \\
\hline Comparison (highest/lowest) & 2.2 & & 2.1 & & \\
\hline \multicolumn{6}{|c|}{ Total phenolics (mg GAE/100 g FW) } \\
\hline Highest & 71.7 & 1 & 70.3 & 4 & 0.9 \\
\hline Midrange & 56.1 & 7 & 56.0 & 5 & 1.0 \\
\hline Lowest & 41.1 & 2 & 44.7 & 1 & 0.9 \\
\hline (highest/lowest) & 1.7 & & 1.6 & & \\
\hline \multicolumn{6}{|c|}{ ABTS antioxidant activity ( $\mu$ mol TEAC/100 g FW) } \\
\hline Highest & 205.6 & 2 & 220.7 & 1 & 1.1 \\
\hline Midrange & 119.6 & 4 & 101.6 & 6 & 0.8 \\
\hline Lowest & 77.3 & 4 & 52.2 & 3 & 0.7 \\
\hline (highest/lowest) & 2.6 & & 4.2 & & \\
\hline \multicolumn{6}{|c|}{ DPPH antioxidant activity ( $\mu$ mol TEAC/100 g FW) } \\
\hline Highest & 301.7 & 1 & 231.7 & 1 & 0.8 \\
\hline Midrange & 243.3 & 1 & 160.9 & 7 & 0.7 \\
\hline Lowest & 162.8 & 8 & 95.0 & 2 & 0.6 \\
\hline (highest/lowest) & 1.8 & & 2.4 & & \\
\hline
\end{tabular}

${ }^{\mathrm{z}}$ Cultivars in high and low classes were significantly different. Comparative gains are between high and low classes to avoid overlapping values in the midrange class. Data compare high with low classes for ascorbic acid, total phenolics, and radical scavenging capacity from ABTS and DPPH assays and from conventional and organic production averaged over 2 years.

${ }^{y}$ Number of cultivars that are significantly different between high and low classes based on Tukey-Kramer mean separation test at $P<0.05$.

Table 5. Dry matter and soluble solids (SSC) for melon cultivars averaged over conventional and organic production by year (means \pm SEM, $\mathrm{n}=6$ ).

\begin{tabular}{|c|c|c|c|}
\hline Year & Cultivar & Dry matter $(\%)$ & Soluble solids \\
\hline \multirow[t]{10}{*}{2005} & Savor & $14.9 \pm 0.1^{\mathrm{z}} \mathrm{ab}$ & $15.1 \pm 0.7 \mathrm{ab}$ \\
\hline & Sweetie \#6 & $15.8 \pm 0.7 \mathrm{a}$ & $16.2 \pm 0.8 \mathrm{a}$ \\
\hline & Burpee Hybrid & $11.5 \pm 0.7 \mathrm{abcd}$ & $12.7 \pm 0.3 \mathrm{bc}$ \\
\hline & Edonis & $13.9 \pm 0.6 \mathrm{abc}$ & $14.7 \pm 0.9 \mathrm{ab}$ \\
\hline & Rayan & $12.6 \pm 0.4$ bcde & $12.5 \pm 0.5 \mathrm{bc}$ \\
\hline & Haogen & $11.3 \pm 0.3 \mathrm{cde}$ & $12.3 \pm 0.9 \mathrm{bc}$ \\
\hline & Swan Lake & $10.7 \pm 0.6 \mathrm{de}$ & $11.1 \pm 0.9 \mathrm{c}$ \\
\hline & Honey Orange & $13.1 \pm 0.6 \mathrm{abcd}$ & $14.2 \pm 0.9 \mathrm{abc}$ \\
\hline & Early Queen & $13.5 \pm 0.2 \mathrm{abcd}$ & $11.8 \pm 0.4 b c$ \\
\hline & Arava & $9.8 \pm 0.3 \mathrm{e}$ & $10.9 \pm 0.5 \mathrm{c}$ \\
\hline \multirow[t]{10}{*}{2006} & Savor & $14.4 \pm 0.9 \mathrm{ab}$ & $14.1 \pm 1.0 \mathrm{ab}$ \\
\hline & Sweetie \#6 & $13.0 \pm 0.7 \mathrm{abc}$ & $12.9 \pm 0.7 \mathrm{abc}$ \\
\hline & Burpee Hybrid & $9.6 \pm 0.3 \mathrm{~d}$ & $9.3 \pm 0.3 \mathrm{~d}$ \\
\hline & Edonis & $10.4 \pm 0.2 \mathrm{~cd}$ & $10.2 \pm 0.3 \mathrm{~d}$ \\
\hline & Rayan & $11.3 \pm 1.1 \mathrm{bcd}$ & $10.9 \pm 0.9 \mathrm{~cd}$ \\
\hline & Haogen & $9.7 \pm 0.4 \mathrm{~d}$ & $10.0 \pm 0.4 \mathrm{~d}$ \\
\hline & Swan Lake & $11.9 \pm 0.6 \mathrm{bcd}$ & $11.9 \pm 0.5 \mathrm{bcd}$ \\
\hline & Honey Orange & $15.4 \pm 0.7 \mathrm{a}$ & $15.6 \pm 0.5 \mathrm{a}$ \\
\hline & Early Queen & $10.9 \pm 0.4 \mathrm{~cd}$ & $10.6 \pm 0.4 \mathrm{~d}$ \\
\hline & Arava & $9.4 \pm 0.6 \mathrm{~d}$ & $9.4 \pm 0.7 \mathrm{~d}$ \\
\hline
\end{tabular}

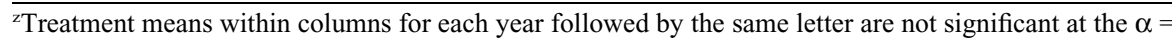
0.05 level according to the Tukey multiple comparison test.

Ascorbic acid. Cultivars varied widely $(P<0.0001)$ in mean ascorbic acid from 16.2 to $38.1 \mathrm{mg} / 100 \mathrm{~g}$ fresh weight. Cultivars Savor and Sweetie \#6 had the highest ascorbic acid content averaged over both years regardless of production system (Table 3). Selecting cultivars for conventional or organic production from those with the highest ascorbic acid values (i.e., 'Savor' and 'Sweetie \#6') over those with the lowest ascorbic acid values provided a potential 2.2- and 2.1-fold increase, respectively. Among cultivars with the highest ascorbic acid, production system made no difference, and midrange and low cultivars were only slightly higher in ascorbic acid when produced organically (Table 4).
Total phenolics. TP also varied $(P<$ 0.0001 ) by cultivar, with 'Savor' having the highest TP under conventional production and 'Sweetie \#6', 'Edonis', 'Honey Orange', and 'Early Queen' having the highest TP under organic production (Table 3 ). Some cultivars differed in TP from 1 year to the next under both production systems indicating that differences in weather events from 1 year to the next and the production system both influenced total phenolic content. TP was 1.6- to 1.7-fold higher for cultivars in the highest versus lowest class (Table 4).

Radical scavenging ABTS and DPPH capacity. Trolox-equivalent antioxidant ca- pacity of cultivars measured with ABTS and DPPH revealed that values ranged more among cultivars $(P<0.0001)$ than from differences resulting from production system or the 2 production years. Cultivar differences for ABTS/TEAC among organic cultivars ranged from a low of $49.0 \mu \mathrm{mol}$ TEAC/100 $\mathrm{g} \mathrm{FW}$ in organic 'Arava' to a high of 220.7 in organic 'Sweetie \#6' averaged over both years (Table 3). Similarly, conventional 'Arava' had the lowest ABTS (55.3 $\mu$ mol TEAC/100 g FW) with 'Savor' having the highest levels $(220.5 \mu \mathrm{mol}$ TEAC/100 g FW). Although large differences were detected among cultivars and between years for both ABTS and DPPH/TEAC radical scavenging capacity (Tables 2 and 3 ), the interactions were not particularly noteworthy. A significant three-way interaction involving ABTS antioxidant capacity was attributed largely to differences between years and to higher values for conventionally produced cultivars Haogen, Edonis, Savor, and Swan Lake (Table 3). Under organic production, selecting the cultivar with the highest TEAC values, Sweetie\#6, over cultivars from the lowest category would enable a 2.6-fold increase in radical scavenging capacity (Table 4). Cultivar comparisons for $\mathrm{DPPH} / \mathrm{TEAC}$ enabled gains of 1.8 -fold for conventional and 2.4-fold for organic production. Except for ascorbic acid, comparing organic with conventional revealed no advantage for organic production (Table 4).

Quality attributes. The percent dry matter and SSC of the 10 melon cultivars for each of the 2 years are shown in Table 5. Although cultivars differed significantly $(P<0.0001)$ for both dry matter and SSC, and values differed significantly $(P<0.01)$ between years, these important quality traits were not impacted by production system (Table 2). In 2005, cultivars Savor and Sweetie \#6 had higher $(P<0.05)$ dry matter than 'Arava', 'Swan Lake', and 'Haogen'. Savor, Sweetie \#6, and Honey Orange cultivars also had higher $(P<0.05)$ dry matter content in 2006 compared with 'Burpee Hybrid', 'Haogen', and 'Arava'.

Correlation analyses. Dry matter and SSC were significantly and highly correlated in $2005(r=0.78, P<0.0001)$ and in $2006(r=$ $0.95, P<0.0001)$ (Table 6). Cultivars with the highest dry matter and SSC also had the highest AA, TPs, and radical scavenging capacity, although more so in 2006 than in 2005. Although cultivars with the highest AA and TP also had the highest ABTS and DPPH radical scavenging capacity in 2006, this relationship did not hold in 2005 (Table 6).

\section{Discussion}

Of the four primary objectives, the most compelling finding is that differences among cultivars contributed the largest range in AA and TP content as well as ABTS and DPPH antioxidant radical scavenging properties, dry matter, and SSC. Although our study was limited to only 10 cultivars, the differences 
Table 6. Correlation matrix (Pearson $r$ ) for antioxidant properties, soluble solids, and dry matter for 2005 (upper right) and 2006 (lower left) with organic and conventional production methods combined ( $\mathrm{n}=60$ for each correlation).

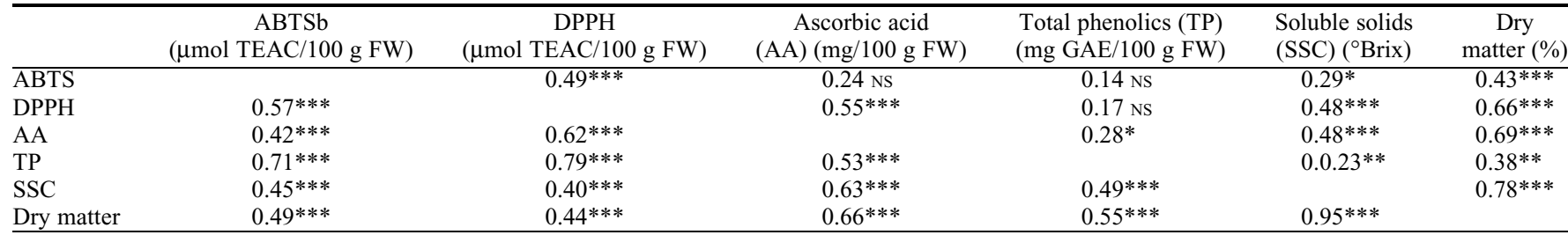

${ }_{\mathrm{N}}^{\mathrm{NS},}, * * * * *$ Nonsignificant or significant at $P \leq 0.05,0.01,0.001$, respectively.

discovered suggest additional investigations may uncover cultivars with attributes superior to those we examined and thus provide improved options for growers to manage a quick and cost-effective means of producing melons for consumers seeking produce with high antioxidants and quality attributes. Although comparative data suggest some gain may be expected from organic production, and climatic conditions from 1 year to the next can be expected to impact antioxidant and quality properties, selection of cultivars is the most important factor in seeking this market niche.

Aside from the fact that cultivars vary considerably, assessment of antioxidant properties is further complicated by environmental conditions from 1 year to the next. Cultivars with the highest levels of TP tended to have the highest radical scavenging capacity in 2006, but not so in 2005. This suggests that either TP was highly influenced by environment or some factor such as endogenous antioxidant enzyme activity not identified in this work was more pronounced in 2005 than 2006. The year effect may have been related to biotic stress in the form of insect pest attack or simply the result of differences in weather patterns such as higher GDD accumulation and/or exposure to high temperature stress just before harvest. In 2005 , melon transplants were heavily challenged by western cucumber beetle ( $A$. vittatum, Fabricius), but interactions with production system and weather complicate drawing convincing causative reasons. When subjected to stresses, antioxidants are produced by some plants to minimize and suppress the production of reactive oxygen species (Smirnoff, 1998). Young et al. (2005) reported an increase in the level of TP in organic pac choi samples that was attributed to flea beetle infestations in organic plots. Although differences in antioxidant composition and activity may be attributed to pest infestation, this would be more convincing with additional studies.

Production system also influenced the antioxidant properties of melon cultivars. To the best of our knowledge, this is the first report that compares antioxidant content and activity of organic and conventionally grown melon cultivars. The results, based on 2 years' data, suggest that melon cultivars grown in organic plots have slightly higher ascorbic acid than those grown in conventional plots. In organic production, nitrogen is slowly released and vegetative growth is not extended giving way to appropriate time to begin the reproductive stage. According to Benbrook et al. (2008), plants trigger activity of the ascorbic acid biosynthetic pathway when the reproductive cycle of the plant has started. In conventional production with periodic excess nitrogen, a prolonged vegetative cycle may deter ascorbic acid production in the fruit. Organic melons also had higher TP than conventional melons but only in the first year.

Radical scavenging capacity was higher in some cultivars than others and varied

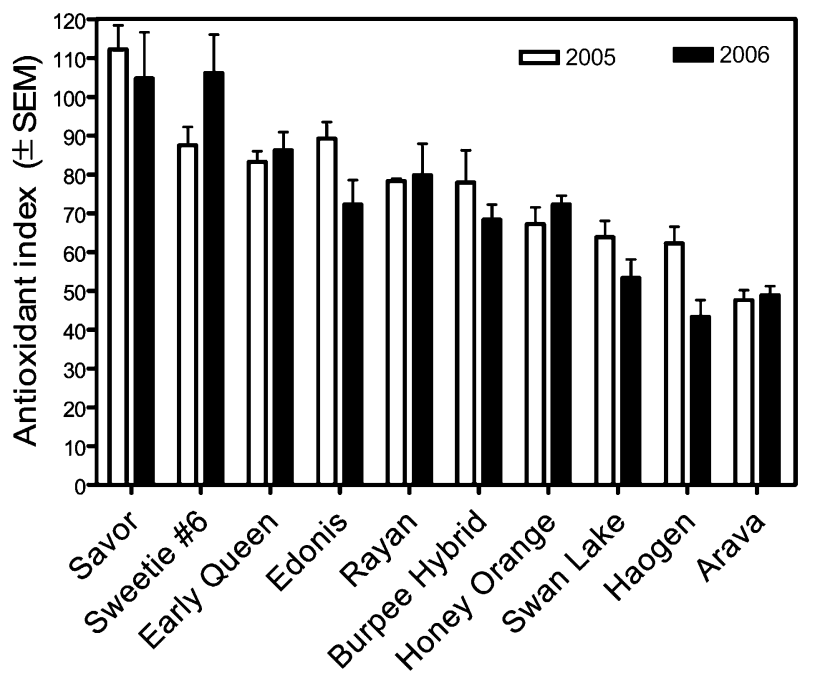

Fig. 2. Antioxidant index $[(\Sigma \mathrm{Vit} \mathrm{C}+\mathrm{TP}+$ antioxidant capacity $) / 3]$ for 10 melon cultivars $( \pm \mathrm{SEM}, \mathrm{n}=6)$ based on three replicate plots from both organic and conventional production. $\mathrm{TP}=$ total phenolics.

by year, but no major trends could be related to production system. Although TP correlated with $\mathrm{ABTS}^{+}$and $\mathrm{DPPH}^{+} / \mathrm{TEAC}$, the relationship was stronger in 2006 than in 2005 (Table 6). These observations suggest that although TP likely provided antioxidant properties, other antioxidants that we did not specifically target such as the carotenoids and perhaps unknown endogenous antioxidant enzymes may also have contributed to responses in the radical scavenging assays.

Among the factors that were examined, cultivar played a major role in determining antioxidant properties in melons. The 10 melon cultivars varied significantly in terms of their AA and TP content and free radical scavenging capacity for both years suggesting high antioxidant diversity among melon cultivars. Lester and Crosby (2002) also found with green-fleshed honeydew muskmelons that cultivar (genetics) had a highly significant effect $(P<0.001)$ on ascorbic acid. Although year (environment) was significant in our study, it was not in Lester and Crosby's (2002). Other studies have reported considerable genetic variability for antioxidant content and activity among tomato cultivars (Spencer et al., 2005), black currant (Tabart et al., 2006), apple (Al-Turki et al., 2008; Stushnoff et al., 2003), potato (Stushnoff et al., 2008), and pear (Galvis Sanchez et al., 2003).

Some cultivars had higher antioxidant properties regardless of production method. The antioxidant index presented in Figure 2 compares the antioxidant potential of the melon cultivars evaluated by combining AA and TP with the average of TEAC values obtained from DPPH and ABTS assays to incorporate free radical scavenging capacity. Examination of rank based on the index over both years reveals that cultivars with the highest and lowest rank generally occupied similar positions among the 10 examined. This suggests that the index provided a reasonably consistent estimate of antioxidant properties for the 10 cultivars. The top index ranks of cultivars Savor, Sweetie \#6, and Early Queen parallel their averaged TEAC ranks. All three cultivars have orange-colored flesh from high concentrations of carotenoids (Lester and Eischen, 1996; Robinson and Decker-Walters, 1999; Saftner et al., 2006), which likely contributed to their high TEAC values. The lowest ranked cultivars, Swan Lake, Haogen, and Arava, have greenish white flesh. 
Melons grown in organic and conventional plots did not display significant differences in dry matter. Magkos et al. (2003) suggested significant differences in dry matter could not be expected between organic and conventional produce because fruits have low ability to absorb and assimilate nitrogen. SSC also was not significantly influenced by different production systems, but the interactive effects (year $\times$ cultivar) were observed to have a significant effect on dry matter and soluble solids. Not surprisingly, high dry matter melons also had the highest soluble solids. The highest dry matter cultivars also had the highest antioxidant properties, AA, and TP content.

Studies that evaluate attributes of produce grown under organic and conventional practices (Asami et al., 2003; Lombardi-Boccia et al., 2004) have encountered skepticism, often for valid but unavoidable reasons related to difficulties in making unambiguous comparisons. Accordingly, after examination of our data and recent literature (Lester, 2006; Magkos et al., 2003; Zhao et al., 2006), the following may provide some guidelines to help avoid pitfalls and improve interpretation. To the extent possible, research targeted at comparing organic production to conventional management should strive to meet the following conditions: 1) locate research plots on soils with similar texture, fertility status, drainage, and exposure, as close to each other as practical while meeting organic certification requirements for the organic plots; 2) include comparison of known identical cultivars within a genotype and crop to minimize complications of genetic traits from unknown cultivars as a variable; 3) repeat the experiment at least 2 years or growing seasons; 4) apply similar production practices, including planting time, planting methods, plot design, spacing, row orientation, irrigation source, application method, and scheduling with care to avoid water stress conditions; 5) to the extent possible, apply similar quantities of major nutritional elements (organic matter will of necessity differ, as in all likelihood will those minor elements associated with organic sources); 6) use similar postproduction harvest methods, including physiological maturity, fruit size, harvest time of day, fruit location on plants, storage conditions, and handling for samples collected for analytical purposes; 7) minimize potential losses by: a) rapid cooling and freezing, b) holding tissue at $-20{ }^{\circ} \mathrm{C}$ or lower, c) preparing liquid nitrogen powders or freeze drying of tissues in a temperature controlled freezer drier after initial freezing to at least $-40{ }^{\circ} \mathrm{C}$, and d) analyzing material within 6 to 12 months from harvest; and 8) use at least three standard analytical methods to assess antioxidant properties with sufficient biological replication and laboratory precision to facilitate statistical analysis.

Drawing appropriate conclusions on the effect of production system on antioxidant properties and fruit quality attributes relies on good experimental design and sampling; nevertheless, year-to-year environmental effects complicate interpretation of data. The results of this study indicate that in general, production system had less effect than cultivar and year differences. Choice of cultivar, unlike weather, can largely be controlled by the producer and is the simplest decision with a large potential impact to optimize nutritional attributes of melon production. Local organic and/or conventional producers who want to take advantage of markets for more nutritious produce can benefit by selecting appropriate cultivars provided unbiased research data on adapted cultivars is available through university extension programs. Although producers are often in a good position to assess local adaptability, assessment of unbiased nutritional properties requires analytical data that are likely best provided by research laboratories.

\section{Literature Cited}

Al-Turki, S., M. Shahba, P. Forsline, and C. Stushnoff. 2008. Biodiversity of total phenolics, antioxidant capacity, and juice quality in apple cider taxa. Hort. Environ. Biotechnol. 49:409-417.

Asami, D.K., Y.J. Hong, D.M. Barrett, and A.E. Mitchell. 2003. Comparison of the total phenolic and ascorbic acid content of freeze-dried and air-dried marionberry, strawberry, and corn grown using conventional, organic, and sustainable agricultural practices. J. Agr. Food Chem. 51:1237-1241.

Bazzano, L.A., M.K. Serdula, and S. Lu. 2003. Dietary intake of fruits and vegetables and risk of cardiovascular disease. Curr. Atheroscler. Rep. 5:492-499.

Benbrook, C., X. Zhao, J. Yañez, N. Davies, and P. Andrews. 2008. State of science review: New evidence confirms the nutritional superiority of plant-based organic foods. The Organic Center. 9 July 2009. <http://www.organic-center. org/reportfiles/5367_Nutrient_Content_SSR_ FINAL_V2.pdf>.

Brandt, K. and J.P. Molgaard. 2001. Organic agriculture: Does it enhance or reduce the nutritional value of plant foods? J. Sci. Food Agr. 81:924-931.

Butelli, E., L. Titta, M. Giorgio, H. Mock, A. Matros, S. Peterek, E.G.W.M. Schijlen, R.D. Hall, A.G. Bovy, J. Luo, and C. Martin. 2008. Enrichment of tomato fruit with healthpromoting anthocyanins by expression of select transcription factors. Nat. Biotechnol. 26:1301-1308.

Caris-Veyrat, C., M.J. Amiot, V. Tyssandier, D. Grasselly, M. Buret, M. Mikolajczak, J.C. Guilland, C. Bouteloup-Demange, and P. Borel. 2004. Influence of organic versus conventional agricultural practice on the antioxidant microconstituent content of tomatoes and derived purees; consequences on antioxidant plasma status in humans. J. Agr. Food Chem. 52:6503-6509.

Cheng, K.W., Q. Wu, Z.P. Zheng, X. Peng, J.E Simon, F. Chen, and M. Wang. 2007. Inhibitory effect of fruit extracts on the formation of heterocyclic amines. J. Agr. Food Chem. 55:10359-10365.

Czernichow, S., J. Blacher, and S. Hercberg. 2004. Antioxidant vitamins and blood pressure. Curr. Hypertens. Rep. 6:27-30.

Esparaza-Rivera, J.R., M.B. Stone, C. Stushnoff, E. Pilon-Smits, and P.A. Kendall. 2006. Effects of ascorbic acid applied by two hydrocooling methods on physical and chemical properties of green leaf lettuce stored at $5{ }^{\circ} \mathrm{C}$. J. Food Sci. 71:S270-S276.

Galvis Sanchez, A.C., A. Gil-Izquierdo, and M.I. Gil. 2003. Comparative study of six pear cultivars in terms of their phenolic and ascorbic acid contents and antioxidant capacity. J. Sci. Food Agr. 83:995-1003.

Lata, B. 2007. Relationship between apple peel and the whole fruit antioxidant content: Year and cultivar variation. J. Agr. Food Chem. 55:663671.

Lester, G.E. 2006. Organic versus conventionally grown produce: Quality differences, and guidelines for comparison studies. HortScience 41:296-300.

Lester, G.E. and K.M. Crosby. 2002. Ascorbic acid, folic acid, and potassium content in postharvest green-flesh honeydew muskmelons: Influence of cultivar, fruit size, soil type, and year. J. Amer. Soc. Hort. Sci. 127:843847.

Lester, G.E. and F. Eischen. 1996. Beta-carotene content of postharvest orange fleshed muskmelon fruit: Effect of cultivar, growing location and fruit size. Plant Foods Hum. Nutr. 49:191197.

Lister, C. 2003. Antioxidants: A health revolution. New Zealand Institute for Crop and Food Research Limited, Private Bag 4704, Christchurch, New Zealand.

Lombardi-Boccia, G., M. Lucarini, S. Lanzi, A. Aguzzi, and M. Cappelloni. 2004. Nutrients and antioxidant molecules in yellow plums (Prunus domestica L.) from conventional and organic productions: A comparative study. J. Agr. Food Chem. 52:90-94.

Lu, Y.R. and L.Y. Foo. 2000. Antioxidant and radical scavenging activities of polyphenols from apple pomace. Food Chem. 68:8185.

Lucier, G. and A. Jerardo. 2007. Vegetables and melons situation and outlook yearbook. Market and Trade Economics Division, Economic Research Service, U.S. Department of Agriculture, Washington, DC. 9 July 2009. <http:// www.ers.usda.gov/Publications/VGS/2007/ 07JulYearbook/VGS2007.pdf>

Magkos, F., F. Arvaniti, and A. Zampelas. 2003. Organic food: Nutritious food or food for thought? A review of the evidence. Intl. J. Food Sci. Nutr. 54:357-371.

Miller, N.J. and C.A. Rice-Evans. 1997. Factors influencing the antioxidant activity determined by the ABTS radical cation assay. Free Radic. Res. 26:195-199.

Pollack, S.L. 2001. Consumer demand for fruits and vegetables: The U.S. example. In: Regmi, A. (ed.). Changing structure of global food consumption and trade. Economic Research Service, U.S. Department of Agriculture, Washington, DC. 9 July 2009. < http://www.ers.usda.gov/publications/ wrs011/wrs011h.pdfs.

Ren, H.F., H. Endo, and T. Hayashi. 2001. Antioxidative and antimutagenic activities and polyphenol content of pesticide-free and organically cultivated green vegetables using water-soluble chitosan as a soil modifier and leaf surface spray. J. Sci. Food Agr. 81:14261432.

Robinson, R.W., and D.S. Decker-Walters (eds.) 1999. Cucurbits. CAB International, New York, NY.

Saftner, R., J.A. Abbott, G. Lester, and B. Vinyard. 2006. Sensory and analytical comparison of orange-fleshed honeydew to cantaloupe and 
green-fleshed honeydew for fresh-cut chunks. Postharvest Biol. Technol. 42:150-160.

Schreiner, M. and S. Huyskens-Keil. 2006. Phytochemicals in fruit and vegetables: Health promotion and postharvest elicitors. Crit. Rev. Plant Sci. 25:267-278.

Smirnoff, N. 1998. Plant resistance to environmental stress. Curr. Opin. Biotechnol. 9:214-219.

Spanos, G.A. and R.E. Wrolstad. 1990. Influence of processing and storage on the phenolic composition of Thompson seedless grape juice. J. Agr. Food Chem. 38:1565-1571.

Spencer, J.P.E., G.G.C. Kuhnle, M. Hajirezaei, H.P. Mock, U. Sonnewald, and C. Rice-Evans. 2005. The genotypic variation of the antioxidant potential of different tomato varieties. Free Radic. Res. 39:1005-1016.

Stushnoff, C., D. Holm, M.D. Thompson, W. Jiang, H.J. Thompson, N.I. Joyce, and P. Wilson. 2008. Antioxidant properties of cultivars and selections from the Colorado potato breeding program. Amer. J. Potato Res. 85:267-276.
Stushnoff, C., A.E. McSay, P.L. Forsline, and J. Luby. 2003. Diversity of phenolic antioxidant content and radical scavenging capacity in the USDA apple germplasm core collection. Acta Hort. 623:305-311.

Tabart, J., C. Kevers, J. Pincemail, J.O. Defraigne, and J. Dommes. 2006. Antioxidant capacity of black currant varies with organ, season, and cultivar. J. Agr. Food Chem. 54:6271-6276.

Thilmany, D., C.A. Bond, J.K. Bond, C. Stushnoff, F. Stonaker, M. Bunning, and P. Kendall. 2007. Eat your fruits and veggies: Exploring freshproduce market choices. J. Food Distribution Res. 38:155-160.

van't Veer, P., M.C.J.F. Jansen, M. Klerk, and F.J. Kok. 2000. Fruits and vegetables in the prevention of cancer and cardiovascular disease. Public Health Nutr. 3:103-107.

Weibel, F.P., R. Bickel, S. Leuthold, and T. Alfoldi. 2000. Are organically grown apples tastier and healthier? A comparative field study using conventional and alternative methods to measure fruit quality. Acta Hort. 517:417426.

Yiridoe, E.K., S. Bonti-Ankomah, and R.C. Martin. 2005. Comparison of consumer perceptions and preference toward organic versus conventionally produced foods: A review and update of the literature. Renewable Agr. Food Systems. 20:193-205.

Young, J.E., X. Zhao, E.E. Carey, R. Welti, S. Yang, and W. Wang. 2005. Phytochemical phenolics in organically grown vegetables. Mol. Nutr. Food Res. 49:1136-1142.

Zhao, X., E.E. Carey, W.Q. Wang, and C.B. Rajashekar. 2006. Does organic production enhance phytochemical content of fruit and vegetables? Current knowledge and prospects for research. HortTechnology 16:449-456.

Zhao, X., E.E. Carey, J.E. Young, W.Q. Wang, and T. Iwamoto. 2007. Influences of organic fertilization, high tunnel environment, and postharvest storage on phenolic compounds in lettuce. HortScience 42:71-76. 